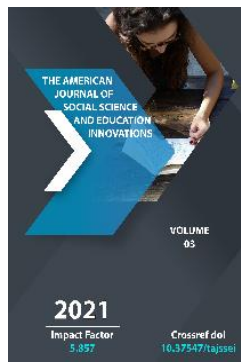

\title{
Youth Sociolect In The Discourse Of Network Forum
}

\author{
Akramova Nozima Muzaffarovna \\ PhD Student, Ferghana State University, Ferghana City, Uzbekistan
}

Journal Website:

https://theamericanjou

rnals.com/index.php/ta

jssei

Copyright: Original content from this work may be used under the terms of the creative commons attributes 4.0 licence.

\section{ABSTRACT}

The article deals with the linguistic and culturological field "Internet" in modern youth sociolect. The author of the article considers that the functioning of language in the global Internet has been studied by many linguists. The change of linguistic personality occurs in conjunction with the formation of a virtual picture of the world, including the linguistic one, reflecting life in the space of Internet with its specific features. All this significantly affects the linguistic situation and requires serious linguistic research.

\section{KEYWORDS}

Youth Sociolect, Specific Nominations, Conventional Language, Common, Internet, Communication, Integrity, Stability, Sub-Standard, Linguistic Specifics.

\section{INTRODUCTION}

Youth sociolect has become an object of study in linguocultural studies at the present stage of scientific development. The conditionality of the notion of "youth language" is expressed in the fact that "the set of specific nominations and expressions, considered as youth language, is not distinguished by strict integrity and stability, as the notion of youth itself is not distinguished by integrity and stability of limitedness" [4, p. 34].

The conventional language of youth expresses a special type of culture - "youth subculture". The emergence of the sub-standard language of youth is connected with the desire of the 
younger generation to separate from adult culture. In order to become "one's own" in the youth community, a young person has to speak a language peculiar to his or her age group [5].

The main parameters of youth speech are age (schoolchildren, students, etc.), social affiliation (profession), territorial feature (city, village), gender criterion, as well as the degree of education of native speakers [3].

The language of young people includes "words that are not found in the common language. The meanings of such words reflect the ideas peculiar to certain groups of young people related to their everyday life" [4, p. 28].

\section{DISCUSSION}

The conventional language of youth also includes common words that have become common due to the blurred boundaries of the conventional language (e.g. баксы, атас, забить стрелку), and words that have become common among the youth of a particular social group (e.g. буль, бэдрип, бэн, дима, шпигануться). Through the Internet youth do shopping, communicate, get information about all aspects of life, realize gambling cravings and much more. Internet communication plays an extremely important role in the lives of teenagers. This is due to the fact that young people spend most of their free time in the Internet. Internet communication often supersedes live communication. In the Internet communication teenagers develop their own language, different from adults, which expresses youth subculture. Characteristics of youth communication are relaxed, informal, joking tone of communication, a high degree of emotionality, the desire for non-standard self-expression inherent in this age group [2]. The language of Internet communication is also unique because it contains not only units of live communication
- words used in oral and written form, but also words created specifically for Internet communication. The role of foreign (mostly English) abbreviations in this lexical-semantic subgroup is great: aфаиp//Afair an acronym for English 'As Far As Remember' // 'насколько я помню; имхо//Imho an acronym for English "in my humble opinion" // “по моему скромному мнению”; лол//LOL (Laugh out loud) is used to compliment a person's sense of humor, or to express disrespect for an opponent's arguments: LOL)).

\section{RESULTS}

Conducted research in the target sphere has shown that the microfield "informational space" includes the following microfields: "information space", "Internet communication", "means of communication". The microfield "information space" includes semantic signs: "global computer network", "e-mail address", "search engine", "file", "Internet program", "download information", "site", "link", "livejournal.com server", "formatting program", "name in the Internet network", "information volume", "antivirus program".

The "amount of information" sign: Кил, кило // Kil, kilo 'kilobyte', мemp // meter 'megabytes', гектар, гиг // hectare, gig. 'gigobytes', mepuк // teric 'terabyte'.

Examples: Я скачал deb размером в 300 c копейками кило и установил foobnix; желающие могут скачать 70 метров отсюда и убедиться в этом лично. // І downloaded a 300 kilo .deb and installed foobnix; You can download 70 meters from here and see for yourself.

The sign "site design <blog>": aва, авчик, аватарка, аватар // ava, avchik, avataka, 
avatar 'the picture that the user chooses as his "face"'.

Examples: Я даже на авчик в контакте поставила. Красивый авчик! Это же аватарка. Кстати, как появился ник? Что означает аватарка? // l even put it on my avchik in contact. It's a beautiful avatar! It's an avatar. By the way, how did the nickname come about? What does the avatarka mean?

The "antivirus program" sign: Kacnep, Kaсnерыч, Kaunepский'Kaspersky Anti-Virus’.

Examples: Я еще не видел ни одной версии каспера, чтобы она не подтормаживала машину. Аваст и каспер - оба за деньги. Проверила комп Каспером, но тот вирусов не обнаружил.// I have yet to see a single version of kasper that doesn't slow down the machine. Avast and Kaspersky - both for money. I checked my computer with Kasper, but it didn't find any viruses.

The sign "e-mail address" contains units: aŭnu, айпишник 'IP-адрес'.

Examples: Ну mаки вы хотите сказать, что не знаете, что такое айпи? Вы думаете, ваш aйnи не позволит вас найтиорганам? // So you're saying you don't know what an IP is? You think your IP won't let the authorities find you?

The sign "searcher" includes the lexemes: гоголь // gogol 'search system Google'.

Examples: Хотелось бы собрать приемы написания поисковых запросов, которые у вас реально работают в гоголе.// I'd like to collect the search query writing techniques that you really have working in gogol.
The "format program" sign: лже-кат, лажакат (from English LJ-cut - live journal cut) 'a text formatting element in live journal' is used to denote a link under which you can "hide" long text or an overly large picture.

Examples: $A$, понятно, лже-кат называется. А у тебя лже-кат не работает, да? // Oh, I see, it's called a LJ-cut. And your LJ-cut doesn't work, does it?

The sign of "hacking": xayumb, xaкamь "hack into anything'.

Examples: Ничего хачить или тюнить тут не нужно. Меня не нуж-но ничему учить, мне не нужно ничего хачить. // You don't have to hack or tune anything here. I don't need to be taught anything, I don't need to hack anything.

The sign "name in the Internet": никнейм, ник 'nickname, alias'. Examples: Простume, я здесь новенькая и еще не разобралась кто здесь кто. Думала вы мужчина, ник у вас mакой и на аватарках почти у всех коты.// Sorry, I'm new here and haven't figured out who's who yet. I thought you were a man, that's your nick and almost everyone has cats on their avatars.

The "file" sign: ammay 'attached file'.

Examples: Turtseva omnравил на почту два письма - в каждом по файлу в аттаче. // Turtseva sent two e-mails, each with a file in the attach.

The "mail" sign: аутглюк 'почтовый клиент MS Outlook'// Outglyuk 'MS Outlook email client'.

Example: Попробуйте в распечатке классического расписания из того же аутглюка перенести или разбить 
выполнение задачи.// Try in the classic schedule printout from the same outglyuk to reschedule or split the task.

\section{CONCLUSION}

Thus, the Internet makes it possible to increase the degree of linguistic communication both in communication over long distances as well as within local society. People have become most knowledgeable through access to an e-mail system that serves as a means of communication between them. Slang is of a great interest and is widely used in youth Internet correspondence. Slang does not remain constant. As one fashionable phenomenon is replaced by another, old words are forgotten and replaced by new ones [1]. As the most fluid and important phenomenon, the slang of young people is not yet settled in time, so there are certain difficulties in its research. Openness of young people to the new, vivid assertion of their own interests, the desire to stand out from the crowd and have fun - all this affects the vocabulary composition, the inconstancy and flexibility of expressions.

\section{REFERENCES}

1. Akramova, N. M., \& Davlyatova, G. N. Reasons of new words formation in youth sociolect. EPRA International Journal of Research and Development (IJRD) Volume, 6.

2. Akramova, N. M., \& Burkhonova, G. Y. (2020). The study and description of a youth sociolect. In European research: innovation in sceance, education and technology (pp. 69-71).

3. Nozima, A. (2021). Scientific Approaches to the Study of Youth Sociolect in Linguistics. Бюллетень науки и практики, 7(4), 541545.
4. Khimik V.V. (2000). Poetics of Low or Common Thought as a Cultural Phenomenon. Publishing house of St. Petersburg State University, pp.28-34

5. Miraleva O.D. (1994). Modern Russian youth slang (sociolinguistic research). Moscow, p.56. 